\title{
Sosyal Hizmet Eğitiminde Teori ve Pratiği Bütünleştirmede Bir Yöntem Olarak Simule Müracaatç1lar
}

\author{
DOI: $10.26466 /$ opus.753971
}

$*$

\section{Eda Beydili Gürbüz *}

\author{
* Dr. Öğr. Üyesi, Düzce Üniversitesi Sağllk Bilimleri Fakültesi Sosyal Hizmet Bölümü \\ E-Posta: edagurbuz@duzce.edu.tr \\ ORCID: $\underline{0000-0003-1680-5439}$
}

\section{$\ddot{O} z$}

Alan uygulaması sosyal hizmet eğitiminin vazgeçilmez bir parçasıdır. Ĕ̆itimleri boyunca birey, grup ve toplumla çalışmaya yönelik bilgi, beceri ve değer temelinde farklı bilgiler alan sosyal hizmet bölümü öğrencilerinden, aldıkları bu eğitimi uygulamaya aktarmaları beklenmektedir. Yapılan çalışmalar öğrencilerin teorik eğitimi pratiğe aktarmakta sorunlar yaşadıkların göstermektedir. Öğrencilerin bu aktarımı nasıl gerçekleştirebileceklerini gerçek müracaatçılarla karşılaşmadan görmeleri, mesleki gelişimleri açısından oldukça önemlidir. Bunun için sosyal hizmet eğitiminde sıklikla kullanılan rol oynama tekniği yerine "daha gerçekçi olan" simüle müracaatçılar dünyada yaygın bir biçimde kullanılmaktadır. Başta tıp, hemşirelik olmak üzere sağllk alanındaki uygulamal pek çok disiplinde yaygin bir biçimde kullanılan simüle müracaatçılar, öğrencilerin aldıkları teorik eğitimi pratiğe aktarmalarında yararlılı̆̆ araştırmalarla da ortaya çıkarılmış bir yöntemdir. Bu kapsamda çalışmada ilk olarak simülasyon yönteminin tanımı ve kapsamı ile sosyal hizmet eğitiminde kullanımı hakkında bilgi verilmektedir. Daha sonra ise simüle müracaatçıların eğitimde kullanılması yoluyla ĕ̆itimin niteliğinin artacağı, mesleğin bilimsel temeline ve toplumsal tanınırlı̆̆ına katkıda bulunacağı düşüncesinden hareketle simüle müracaatçıların yetiştirilmesi önerilmektedir.

Anahtar Kelimeler: simülasyon, rol oynama, simüle müracaatçl, sosyal hizmet uygulaması, sosyal hizmet eğitimi 


\title{
Simulated Clients as a Method for Integrating Theory and Practice in Social Work Education
}

\begin{abstract}
Field practice is an indispensable part of social work education. Social work students, who receive different information on the basis of knowledge, skill and value for working with individuals, groups and society during their education, are expected to put this education into practice. Studies show that students have problems transferring theoretical education to practice. It is very important for students to see how they can achieve this transfer without encountering real clients. For this, "more realistic" simulated clients are used instead of the role playing technique frequently used in social education Simulated clients, which are widely used in many disciplines in the field of healthcare, especially in medicine and nursing, are also a method that has been revealed by researches, in order to transfer students' theoretical education to practice. In this context, firstly, information about the definition and scope of the simulation method and its use in social work education is given. Then, it is recommended to train simulated clients based on the idea that the quality of education will increase through the use of simulated clients in education and will contribute to the scientific base and social recognition of the profession.
\end{abstract}

Keywords: Simulation, role-play, simulated client, social work practice, social work education 


\section{Giriş}

Sosyal hizmet eğitiminin iki yönü vardır: Bunlardan birincisi sınıf içerisinde verilen teorik eğitim iken, diğeri alan uygulamasıdır. Lisans öğrenimi boyunca öğrenciler, sosyal sorunlardan insan davranışı ve sosyal çevreye; sosyal hizmet kuramlarından çocuk, engelli, kadın, yaşlı vb. farklı nüfus gruplarını anlamaya ve bu gruplarla çalışmaya yönelik çeşitli dersler almaktadırlar. Derslerinde farklı alanlarda birey, grup ve toplumla çalışmak amaciyla farklı yöntem ve teknikler öğrenen öğrencilerden, bu öğrendiklerini uygulamaya aktarması beklenmektedir. Alan uygulaması çerçevesinde öğrenciler; sosyal, ekonomik, politik vb. sistemlerin insanların yaşamları üzerindeki etkisini anlama ve değerlendirme becerisi kazanarak gerçek yaşama hazırlanmaktadır (Duyan, 2010). Sosyal hizmet eğitiminin vazgeçilmez bir parçası olarak alan uygulaması, öğrencilerin sosyal hizmet uzmanı olarak çalıştıklarında hata yapmalarının önüne geçmede çok önemli bir rol oynar. Badger ve MacNeil (1998) sosyal hizmet eğitimi ile öğrencilerin uygulama alanındaki performansı arasında bir boşluk olduğunu ifade etmektedir. Nitekim Erbay ve Sevin (2013) 'in sosyal hizmet son sınıf öğrencileriyle yapmış oldukları araştırmada; öğrenciler teori ve pratik arasındaki ilişkinin derslerde kurulamadığını, uygulama derslerindeki zorlukların da eklenmesiyle kendilerini mesleki anlamda yeterli hissetmediklerini ifade etmişlerdir. Erbay, Adıgüzel ve Akçay (2013)'ın sosyal hizmet son sınıf öğrencileri ile yaptıkları araştırmada ise öğrencilerin \%61,5'inin kendilerini alan uygulaması yapmaya hazır hissetmediği ortaya çımıştır. Öğrencilerin \%55'i kendilerini uygulamaya hazır hissetmeme nedenini derslerin teorik odaklı olup, uygulamaya yönelik örnekler görmemek olarak ifade etmiştir. Oysa sosyal hizmet mesleği beceri temellidir ve öğrencilerin öğrendiklerini uygulamaya nasıl aktaracaklarını bilememeleri, alanda müracaatçının sağlığına zarar vererek yaşadığı sorunların daha da derinleşmesi gibi yanlış uygulamalar yapmalarına neden olabilmektedir. $\mathrm{Bu}$ aktarımın nasıl olabileceğini göstermek ise sosyal hizmet eğitimcilerinin temel sorumluluklarındandır.

2008 yılında Sosyal Hizmet Eğitim Konseyi (CSWE) Eğitim Politikası ve Akreditasyon Standartları (EPAS) için "yetkinlik temelli eğitimi (competency based education)" kabul etmiştir. Yetkinlik temelli yaklaşım, öğrencilerin uygulamada nasıl bir performans gösterdiklerini tanımlamayı ve bunu değerlendirmeyi ifade etmekte olup öğrencilerin eğitim içerisindeki yeterliklerini 
gösterme becerisini içermektedir. CSWE, sosyal hizmet eğitiminin amacının öğrencilerin bütüncül bir yetkinlik kazanabilmeleri için bilgi, değer, beceri ve her biri biricik olan uygulama durumları içerisinde karar vermelerini, etkili tepki göstermelerini ve sosyal hizmet uzmanının eleştirel düşünmesini içeren bilişsel ve etkileşimsel süreçleri desteklemek olduğunu belirtmektedir. Bunu başarabilmenin yollarından biri de öğrencilere eğitimleri süresince bunları nasıl bütünleştirebileceklerini öğretmektir (CSWE, 2015). Simülasyonlar bu amacı gerçekleştirmede kullanılan temel tekniklerdendir.

Türk Dil Kurumu'na göre benzetim anlamına gelen simülasyon, gerçekçi bir çevrede gerçek bir sorunu kullanarak eleştirel düşünme, problem çözme ve öğrenmeyi sağlayan yöntem olarak tanımlanmaktadır (Nimmagadda ve Murphy, 2014). Asakura, Bogo, Good ve Power (2018) simülasyonu genel olarak, öğrencilerin iyi tasarlanmış bir vakayı göstermek için eğitilmiş aktörler olarak ifade edilebilecek olan simüle müracaatçılarla görüştükleri durumlar olarak tanımlamaktadır. Sağlık alanıyla ilgili disiplinlerde simüle (simulated) kavramı yerine daha çok "standart hasta ya da standardize hasta (standardized patient)" kavramı kullanılmaktadır. Bir hekim olan Barrows (1993), standardize kavramının, hastalığı belli bir standartta göstermek için eğitim almış kişiyi ifade eden simüle hasta ile hastalığını belli bir standartta sunan gerçek hastaları kapsayan şemsiye bir kavram olduğunu ifade etmektedir. Standart hasta, "belirli bir hastalık öyküsünü tam ve tutarlı bir şekilde betimlemek ve öğrenci performansını değerlendirmek üzere eğitim almış gerçek hasta ya da sağlıklı bir birey" olarak tanımlanmaktadır (Elçin vd.2002, Akt. Çınaroğlu, 2013). Özellikle tıp, hemşirelik, psikiyatri gibi sağlık alanlarında oldukça sık kullanılan simülasyonların farklı biçimleri bulunmaktadır. Sosyal hizmet mesleği de özellikle yurtdışında simülasyonların sıkça kullanıldığı, böylece teorik bilgilerin pratiğe aktarımının öğrenildiği bir alandır.

Simülasyonların sosyal hizmet eğitiminde kullanılması aslında yeni bir durum değildir. İngilizce' de "role play" olarak geçen, Türkçe'ye "rol oynama /yapma" olarak çevrilebilecek olan teknik, sosyal hizmet eğitiminde sıklıkla kullanılan bir simülasyon yöntemidir. Görüşmenin (interview) sosyal hizmet mesleği açısından müracaatçının durumunu anlamak ve sorunlarıyla başa çıkmalarında yardım etmekte kullanılan temel bir araç olduğu göz önüne alındığında, rol oynama simülasyonlarının eğitimde sıklıkla kullanılıyor olması şaşırtıcı değildir (Petracchi ve Collins, 2006). Rol oynama sosyal hizmet uygulamalarının bilgi, değer ve becerilerini elde etme yöntemi olarak kişisel 
gelişim ve öğrenmenin rol oynayarak gerçekleştiği varsayımına dayanır (Hargreaves ve Hadlow, 1997). Rol oynamanın hazırlık, öğrenme hedeflerini netleştirme, zorlu durumlar yaratma, oyunu canlandırma, yeterli zaman verme, tüm öğrencileri içine katma, kuralları belirleme, izleyen öğrencilerin ilgilenmesini sağlama, yapılandırılmış değerlendirme formu kullanma, öğrencilere bilgi verme ve geribildirim alma, yansımayı teşvik etme ve mizah anlayışını koruma gibi bir takım aşamaları olduğunu ifade eden Joyner ve Young (2006), tıpta rol oynama aracılığıyla öğrencilerin hekim rolünde hastanın bilgisini aldığını, teşhis koymak için veri topladığını ve dersi veren kişiden yapıcı eleştiriler aldığını ifade etmektedir. Rol oynama simülasyonları uygulama ve teoriyi birleştirmek için oldukça yararlı bir yöntemdir. Literatürde sosyal hizmet açısından rol oynamanın öğrencilerin mesleki ve kişisel gelişimlerine katkı sunduğunu belirten çalışmalar bulunmaktadır (Whatling ve Wodak, 1979; Hargreaves ve Hadlow; 1997; MacDonald ve Biegel, 2012). Sosyal hizmette rol oynama tekniği kullanılırken, önce var olan gerçeklik eğitmenin o gerçekliğin özünü çıarmasına izin verecek şekillerde kavramsallaştırılarak bir senaryoya dönüştürülmektedir. Daha sonra bu senaryo, katılımcılar tarafından canlandırılmaktadır. Bu süreçte ise notlar alınmakta, ses ve görüntü kaydı yapılmaktadır. Oyundan sonra ise kişilere geribildirim verilerek öğrencinin kendisinin ve becerilerinin farkına varması sağlanmaktadır (Hargreaves ve Hadlow; 1997). Rol oynama simülasyonları, özellikle müracaatçı rolünde olan kişinin gerçekten müracaatçı olmaması, uygulamanın sınıf ortamında yapılmasıyla ilişkili olarak "yeterince gerçek olmaması" (Urdang, 1991 akt. Moordian, 2008) nedeniyle eleştirilmekte ve simüle müracaatçılar kullanılarak yapılan eğitim faaliyetlerinin daha yararlı olduğu belirtilmektedir.

Sosyal hizmet mesleği açısından bakıldığında, çoğunlukla sınıf içerisinde sosyal hizmet uzmanı ve müracaatçı rolüne giren öğrenciler, mesleki görüşme becerilerini kullanarak ders kapsamında beklenen doğru davranışı, duyguyu, düşünceyi, etik tutumu vb. göstermeye çalışmaktadır. Sosyal hizmet eğitiminde her bireyin ve sorunun biricik olduğu, dolayısıyla sorunu o vaka için o koşullarda anlamanın önemli olduğunun altı çizilmektedir. Bu açıdan bakıldığında standardize kavramı, standart müracaatçı olmayacağından sosyal hizmet eğitiminde kullanılamayacağı algısını doğurabilmektedir. Oysa burada esas vurgulanan nokta, rol oynama simülasyonlarının "yete- 
rince gerçek olmadığı" noktasından hareketle sosyal hizmet uzmanı rolündeki öğrencinin karşısına öğrencinin daha önce görmediği, tanımadığı; sorunu duygu, düşünce ve davranışları ile yansitabilen, uzman rolündeki öğrencinin ifadelerine göre eğitmenden daha önceden aldığ bildirimlerle de görüşmenin seyrini değiştirebilecek kişilerin olmasıdır. Bu yolla öğrencilerdeki "karşımdaki arkadaşım, nasılsa gerçek değil, şimdi yaptım/yapmadım ama gerçekte olsa yapardım/yapmazdım" şeklindeki ifadelerin ortadan kalkmasına katkıda bulunulacağı düşünülmektedir.

Sonuç olarak, sosyal hizmet camiasında sosyal hizmet mi yoksa sosyal çalışma kavramı mı tartışması bir yana, Türkiye'nin farklı üniversitelerinde sosyal hizmet eğitimi almamış kişilerce sürdürülen sosyal hizmet eğitimi, alan uygulamasının olmazsa olmaz olduğu bir mesleğin açı öğretimde olmasının, sosyal hizmetin herkesçe yapılabilecek bir meslek olduğu varsayımıyla sosyal hizmet uzmanlarının yapması gereken işlerin sosyal çalışma görevlisi adı altında birçok farklı disiplinden kişilerce yerine getirilmesinin sosyal hizmet eğitimiyle de ilişkili olduğu düşünülmektedir. Eğitimin niteliğinin artttrılması, nitelikli uygulamaları yapacak nitelikli sosyal hizmet uzmanlarının yetiştirilmesine katkı sunacaktır. Farklı öğretim teknikleri kullanmak, niteliği arttırmada küçük ancak önemli bir detaydır. Sosyal hizmet eğitiminde farklı bir teknik olan simüle müracaatçıların kullanımına dikkat çeken bu çalı̧̧mada birçok farklı disiplinde kullanılan simülasyon tekniğinin tanımına, kapsamına ve sosyal hizmet eğitimi içerisinde kullanımına yer verilerek Türkiye'de simüle müracaatçların yetiştirilmesine dair öneri sunulmuştur. Bu yolla, yurtdışında yapılan çalışmalar ve Türkiye'de farklı disiplinler kapsamında simüle müracaatçı kullanılmasından elde edilen yararlar noktası göz önünde tutularak, sosyal hizmet eğitiminin de gelişeceği ve zenginleşeceği, böylece sosyal hizmet mesleğinin bilimsel temellerinin güçlendirilmesi ve toplumsal alanda kabul edilirliğinin artmasına da katkıda bulunulacağı düşünülmektedir.

\section{Simülasyonun Tanımı ve Kapsamı}

Simülasyonun bir teknoloji değil yöntem olduğunu ifade eden Gaba (2004)'ya göre simülasyon, tamamen etkileşimli bir şekilde gerçekte var olan durumların ya da deneyimlerin benzerini yapma veya çağrışım yoluyla bu deneyimleri değiştiren ve geliştiren bir eğitim yöntemidir. Alinier (2007)'e 
göre ise simülasyon, "sistemin davranışını anlamak veya sistemin çalışması için çeşitli stratejileri değerlendirmek için gerçek sistem modelini tasarlama ve bu modelle deneyim kazanma süreci"dir. Bu tanımlardan yola çıkarak simülasyonun en basit anlamda herhangi bir araç, sistem, olay ya da durumun, "oluşturulan benzeri" olduğu söylenebilir.

Simülasyonun tarihsel sürecine bakıldığında, ilk simülasyonların Çin savaş oyunlarından geldiği ve bu oyunlar aracilı̆gyyla ordu ve donanma stratejilerinin gelişimine katkı sunulduğu, daha sonra 1929 yılında Edward Link tarafından ilk uçak simülatörünün geliştirildiği, ilk tıp simülatörlerinin 16-17. yüzyılda "phantom" olarak isimlendirilen, bebek ve anne ölümlerini azaltmak amacı ile obstetrik becerilerin eğitimi ve sınanmasında kullanılan mankenler aracılığıyla yapıldığı, 1990'lı yıllarda tıp eğitimi reformu ile birlikte simülasyonun, tıp öğrencilerinin eğitim ve değerlendirilmesinde kullanımının dünya tarafından tanındığı ifade edilmektedir (Mıdık ve Kartal, 2010)

Simülatörler psikiyatri (Mercan, Tangül Özcan ve Aydın, 2018), hemşirelik (Göriş, Bilgi ve Korkut Bayındır, 2014; Uslu, Yavuz van Giersbergen, 2019), kadın sağlığı (Şendir, 2013), diş hekimliği (Taner, Yılmaz, Küçük, Küçükkaya Eren, 2017), eczacıllk (Sözen Şahne, Ulutaş Deniz ve Yeğenoğlu, 2017), beslenme ve diyetetik (Aksan, Kabasakal Çetin, Ilgaz ve Gökmen Özel, 2017), fizyoterapi ve rehabilitasyon (Kınıkl, Erden, Cavlak ve Erden, 2017) gibi birçok sağlık disiplini tarafından kullanılmakta ya da kullanılmasının yararlı olacağı belirtilmektedir. Simülasyonların özellikle klinik beceri laboratuvarlarında kullanımının giderek yaygınlaştığı ve gerek mezuniyet öncesi gerek de mezuniyet sonrası eğitim programlarının bir parçası haline geldiği ifade edilmektedir (Bradley, 2006).

Sağlık alanındaki eğitimlerde sıklıkla kullanılan simülasyonların, gelişen teknolojiye paralel olarak farklı çeşitleri bulunmaktadır. Miller (1990) Şekil 1'de görüldüğü üzere klinik değerlendirme için dört temel çerçeve olduğunu ifade etmektedir. Miller (1990) 'e göre bir öğrenci ya da hekim, mesleğini daha etkili bir şekilde yapabilmesi için ne gerektiğini bilmelidir. Bu durum öğrencinin mesleki bilgi temelini oluşturmaktadır. Bu temel, sınavlarla ölçülebilmektedir. Uygulamalı bir meslek olan hekimliği sadece bilmek yetmemektedir. Bunun için bilginin nasıl kullanılacağını da bilmek gerekir. Bunun için de insanlardan ya da laboratuvarı kullanarak edindiği bilgileri analiz etmeli, yorumlamalı ve teşhis ve tedavisinde kullanmalıdır. $\mathrm{Bu}$ da onun yetkinliğine 
işaret etmektedir. Öğrencileri değerlendirmek amaciyla yapılan sınavlar, öğrencilerin bildiklerini ve yetkinliklerini ölçebilmekte iken bunun nasıl olduğunu göstermede yetersiz kalmaktadır. Çünkü bunu yapabilmek için öğrencinin hasta ile olan etkileşimini iyi gözlemlemek gerekmektedir. Öte yandan öğrencinin nasıl olduğunu göstermesi, gözlem ya da test edilme ortamı olmadan yapabileceğini gösterebilir mi? Bu son basamağın test edilmesi çok zordur. Tüm bunlardan hareketle öğrencilerin gerçekte meslek elemanı olarak neyi, nasıl yapacaklarını bilmeleri ve göstermelerinin piramitteki tüm basamakların iyi bir şekilde yerine oturması ile gerçekleşebileceği düşünülmektedir.

Alinier (2007), tıp eğitimindeki simülasyonu Miller (1990)'in çalışması üzerinden sıfırıncı düzeyden beşinci düzeye kadar toplam altı düzeyde sınıflamıştır.

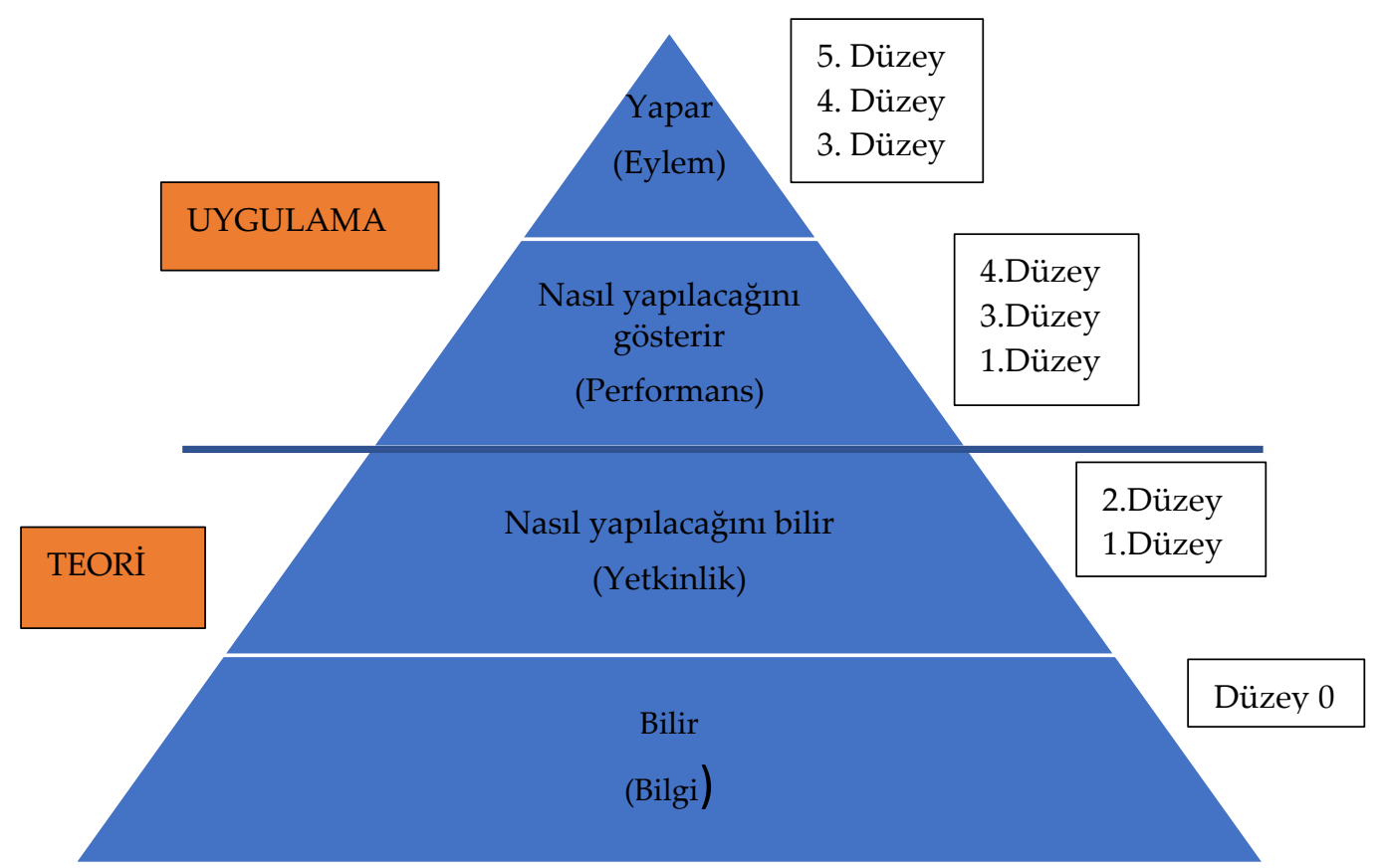

Şekil 1: Simülasyon temelli öğrenme etkinlikleri ile deneyim kazanma çerçevesi (Allinier, 2007). 
Şekle göre 0. Düzey, yazılı simülasyon olarak adlandırılır ve bunu gerçekleştirmek için herhangi bir araca ihtiyaç duyulmamaktadır. Üç boyutlu mankenler 1. Düzey, görsel gerçeklik ve ekran temelli simülasyonlar 2. Düzey, standart ya da gerçek hastalar; 3 . Düzey, orta ve yüksek gerçeklikli simülatörler ise 4. ve 5. Düzey olarak ifade edilmektedir. Düzeyler arttıkça simülasyonun gerçeklik düzeyi artmaktadır.

Gaba (2004) ise simülasyonu sınıflandırırken 11 aşama belirtmiştir. Sınıflamada simülasyonun amaç ve hedefleri, simülasyona katılan birim, katılımcıların seviyesi, simülasyonun uygulandığı alan, simülasyona katılan meslek grubu, simülasyon ile kazandırılmak hedeflenen bilgi, beceri ve tutum alanları, hastanın yaşı, simülasyon yaklaşımları, simülasyon uygulama yeri, katılımın boyutu ve geribildirim yöntemine yer vermektedir

Hayden (Akt. Tüzer, 2019) ise simülasyonda kullanılan simülatörlerin gerçeklik düzeyine göre düşük, orta ve yüksek gerçeklikli simülasyon olarak adlandırır ve standardize/simüle müracaatçları yüksek gerçeklikli olarak tanımlar. Durmaz Edeer ve Sarıkaya (2015) standardize hastaların özelliklerini, vaka çalışmalarında ve rol oynama simülasyonlarında kullanılabilme, bireylerin ve öğrencilerin, ücreti ödenen aktörlerce gerçekçi ve tutarlı bir biçimde canlandırılan hastayı tanımlayabilmesi, fizik muayene tanılayabilmesi ve iletişim becerileri eğitimi için kullanılabilmesi olarak belirtmişlerdir.

Literatürde eğitimde standart hastaların kullanımının yararlarına ilişkin araştırmalar bulunmaktadır. Şahin, Sağır Koptaş ve Buzlu (2019) tarafından şizofreni, majör depresyon ve manik dönemdeki bipolar bozukluğu olan standardize hastalar kullanılarak psikiyatri hemşirelerinin becerileri ölçülmüş ve standardize hasta rolünde profesyonel oyuncunun yer almasının yüksek gerçeklik sağlamada ve ruh sağlığı ve psikiyatri hemşireliği klinik simülasyonunun öğrenim hedeflerine ulaşmada etkili olduğu belirlenmiştir. Sarmasoğlu (2014) yapmış olduğu doktora araştırmasında standart hasta kullanımının hemşirelik öğrencilerinin mesleki sorumluluklarını öğrenmesine olumlu katkı sağladığını, öğrencilerin kendilerine duydukları güveni güçlendirdiğini, gerçek hasta ile gerçekleştirdikleri uygulamada heyecanlarını azalttığını ve hasta ile iletişimlerini kolaylaştırdığını ortaya çıkarmıştır. Şenol, Yardım ve Başarıcı (2014) yapmış oldukları araştırmada, öğrencilerin $\% 84,4$ 'ünün standart hasta uygulamasından memnun olduğunu ve \% 72,2'sinin eğitim sonrasında performansların yeterli hissettiğini belirtmektedir. Yine Dikici ve Yarış (2007) tıp öğrencileriyle yapmış oldukları araştırmada, 
öğrencilerin yapılan simülasyon uygulamasından memnun olduklarını hatta bazen oyuncuları gerçek hasta zannettiklerini ifade etmektedir. Turan, Üner ve Erçin (2011) araştırmalarında simülasyon uygulamasında standart hastadan geribildirimi alan öğrencilerin sınav kaygı düzeylerinin daha düşük, özyeterlilik düzeylerinin daha yüksek olduğunu bu sonucun da öğrencilerin iletişim becerileri eğitiminde standart hastadan geribildirim almalarının onların güdülenme düzeylerini etkilediğini ifade etmektedir.

Daha çok sağlık alanında rastlanılan simülasyonun insani bilimlerde kullanımına son yıllarda bir ilgi gösterilmektedir (Bogo, Regehr, Katz, Logie ve Mylopoulos, 2011; Logie, Bogo, Regehr ve Regehr, 2013; Rawlings, 2012). Bu kapsamda çalışmanın bir sonraki bölümünde simüle müracaatçıların sosyal hizmet eğitiminde kullanımına yer verilmektedir.

\section{Simüle Müracaatçılar Kullanılarak Yapılan Sosyal Hizmet Eğitimi}

İnsan hakları ve sosyal adaleti odağına alan, birey, grup ve toplumların iyilik halinin artırılması ve güçlenmesi için müdahalelerde bulunan sosyal hizmet mesleği açısından, öğrenciler Miller (1990)'in belirttiği tipolojideki adımlarda neleri yapabilmektedir? Örneğin öğrenci, sadece müdahalenin nasıl yapılacağını mı biliyor yoksa sadece bilmekle kalmayıp aynı zamanda bu müdahaleyi uygulayabilir mi? Sosyal hizmet eğitiminde mesleğin sıklıkla bilgi, beceri ve değer temeline sahip olduğu vurgulanmaktadır (Duyan, 2010). Bu noktada özellikle öğrenciler, eğitimleri boyunca çoğunlukla neyin yapılacağı bilgisini öğrenmektedir. Bunun nasıl yapılacağı ise derslerde verilen örnekler, kullanılan rol oynama, soru cevap, vaka çalışması gibi teknikler aracılığıyla anlatılmaktadır. Yapılan değerlendirme sınavlarıyla öğrencilerin bilgileri ölçülmektedir. Dolayısıyla öğrencilerin tipolojideki birinci ve ikinci alt basamağı yerine getirebildiği söylenebilir. Peki öğrenciler aldıkları bu bilgileri uygulayabilecekler midir? Bu sorunun cevabı öğrencilerin beceri repertuvarına bağlı olarak değişmektedir. Sosyal hizmet eğitimcileri bu sorunun cevabını, çoğunlukla öğrencilerin alan uygulamasına başlamasıyla gerçekleştirdikleri süpervizyon toplantılarında almaktadır. Öğrencilerin nasıl bir meslek elemanı olacağı, aldığı teorik bilgiyi pratiğe aktarmadaki başarısı ya da yeterliliği ile kendisini göstermektedir. Uygulama alanında öğrencilerin gösterdikleri mesleki performans, mesleğin bilimsel temelini ve toplumsal tanınırlığını 
doğrudan etkilemektedir. Bu noktada özellikle öğrencilerin aldığı bilgiyi uygulamada kullanması, bunu göstermesi son derece önemlidir. Bunu gerçekleştirebilmeleri için eğitimleri içerisinde öğrenmeleri gerekmektedir. Simüle müracaatçılar bu konuda önemli bir araç olarak karşımıza çıkmaktadır.

1975 yılında BBC kanalında Kanadalı tıp öğrencilerinin, bir hemşire tarafından öyküsü anlatılan engelli simüle hasta üzerinde mesleki becerilerini kullandığı bir program gösterilmiştir. 8 ila 10 öğrenci arasında geçen bu çalışmada eğitici, öğrencileri gözlemlemekte, simüle hastayla görüşmesinden aldığı bildirimlerle uygulamayı yapan öğrencilere geri bildirim vermektedir. Bu programdan hareketle 1977 yılında Cambridge, İngiltere'de bulunan Fulboun Hastanesi Sosyal Servisi'nde deneysel bir çalışma yürütülmüştür. Bu çalışmada öğrenciler, sosyal hizmet eğitiminde simüle müracaatçı ile görüşme kullanılarak değerlendirilmiştir (Whatling ve Wodak, 1976). Son yıllarda sosyal hizmet eğitiminde simüle müracaatçıların kullanımı giderek artmaktadır.

Simüle müracaatçlar, belirlenmiş bir müracaatçının tüm özelliklerini göstermek üzere eğitim almış profesyonel olmayan kişiler olarak tanımlanmaktadır (Badger ve Mcneil, 2002). Eğitimci burada öğrencinin daha önce tanımadığı bir simüle müracaatçı kullanır ve böylece eğitim, gerçek yaşama daha çok benzemektedir. Simüle müracaatçı da uygulama sonunda eğitimci tarafından geliştirilen bir form kapsamında yapıcı geribildirimler vermektedir (Linsk ve Tunney, 1997). Böylesi bir değerlendirmenin Tuncay (2016)'ın işaret ettiği gibi sosyal hizmet uygulamasının kanıtlarla güçlendirilmesine, mesleğin bilimsel temellerinin güçlendirilmesine ve toplumsal kabulünün artmasına katkı sunabileceği düşünülmektedir. Simüle müracaatçı kullanımının rol oynama yönteminden daha çok eğitimsel anlamda katkı sunduğunu belirten Miller (2002), uygulama sonunda simüle müracaatçının verdiği geribildirimlerin çoğunlukla artı eksi olarak işaretlendiği bir kontrol listesi olduğunu, "öğrenci duygu ve düşüncelerime karşıllık verdi, açlk uçlu sorular sordu, sosyal destek kaynaklarıma baktı" gibi sorulardan oluştuğunu, çocuk istismarından madde kullanımına, intihar girişiminden depresyondaki müracaatçıya kadar pek çok noktada becerileri geliştirme olanağı sunduğunu ifade etmektedir.

Özellikle tıp eğitimi için geliştirilmiş, bugün hemşirelikten psikiyatriye kadar farklı alanlarda da kullanılan ve öğrencilerin bilgisinin yanı sıra klinik becerilerini de ölçmeyi amaçlayan Objektif Yapılandırılmış Klinik Sınav 
(OSCE-The Objective Structured Clinical Examination) adlı bir sinav yapılmaktadır. OSCE'de profesyonel uygulamaların bulunduğu ve istasyon olarak adlandırılan birimlerde tıp öğrencisinin klinik becerileri (hasta öyküsü alma, akciğer filmi okuma, enjeksiyon yapma gibi) değerlendirilmektedir. Öğrenci bir gözlemci tarafından gözlemlenmekte ve bu gözlem tek taraflı ayna, bariyer arkasında veya video çekimli odalarda gerçekleşmektedir (Darendeliler, 2002). OSCE'nin özellikle tıp eğitiminde yalnızca bilgiyi değil aynı zamanda klinik beceriyi değerlendiren, yüksek güvenilirliği olan ve standart hasta kullanılması dolayısıyla öğrenciler için adil bir sınav olduğunu belirten Bogo, Regehr, Katz, Logie, Tufford ve Litvack (2012) bu sinavı sosyal hizmet eğitimine uyarlamıştır.

Sosyal hizmet eğitimine uyarlanan OSCE'nin iki bileşeni bulunmaktadır: Bunlardan ilki, eğitimcinin (ders sorumlusunun) gerçek müracaatçı durumuna benzer senaryolar oluşturmak için deneyimli bir sosyal hizmet uzmanı ile çalışarak oluşturduğu ve bir sosyal hizmet uzmanının karşı karşıya gelmesi beklenen bir durumu tasvir eden simüle müracaatçı ile yapılan 15 dakikalık bir görüşmedir. Yazılı açılamalar profesyonel oyuncuları eğitmek ve yeniden paylaşmak için kullanılmaktadır, böylece senaryoyu özgün bir şekilde oynayabilmektedirler. Değerlendirilecek temel yetkinlikleri tanımlayan derecelendirme ölçekleri geliştirilmekte ve değerlendirecek olan kişiler ölçekleri kullanmak üzere eğitilmektedir. Bu kişiler uygulama alanı sorumluları (sosyal hizmet uygulamasındaki kurum danışmanları)ya da ders sorumluları olabilmektedir. Sınavın ikinci bileşeninde öğrenci, görüşme sonrası görüşmeci ile düşünümsel bir görüşme gerçekleştirmektedir. Bu görüşme öğrencinin mülakat konusundaki farkındalığını, sosyal hizmet kavramlarını ve değerlerini nasıl birleştirdiğini ele almayı ve ortaya çıkarmayı amaçlamaktadır. Düşünümsel görüşme, profesyonel uygulamanın daha zor yönlerini tanımlamak ve değerlendirmek için videoya kaydedilmekte ve analiz edilmektedir. Öğrencinin gözlemlendiği ve değerlendirildiği bu sınavın dezavantajı, ortamın yapay doğasından kaynaklanmaktadır (Bogo ve Rawlings, 2016).

Sosyal hizmet açısından yenilikçi ve öğrencileri alana en iyi şekilde hazırlayacak yetkinlikleri içeren bir yöntem olarak ifade edilen simülasyon temelli öğrenmenin (Kourgiantakis, Bogo ve Sewell, 2019) yararlı olduğu, çeşitli araştırmalarla desteklenmektedir. Sosyal hizmet öğrencilerine gerçek müracaatçlarla karşılaşmadan önce değerlendirme becerilerini uygulama firsatı sunmak amacıyla, simüle müracaatçının kabul edilebilirliğini ve etkililiğini test 
etmeyi amaçlayan çalışmalarında Badger ve MacNail (2002) simüle müracaatçlların başka herhangi bir yolla sağlanamayacak bir öğrenme firsatı sunduğunu ifade etmektedir. On iki yüksek lisans öğrencisi ile dokuz ay boyunca üç farklı simülasyonun etkisini araştırmak üzere yapılan nitel çalışmada (Roberson, 2019), uygulamanın öğrencilerin farkındalıklarını arttığı belirtilmektedir. Karma yöntem kullanılan bir başka çalışmada, simüle edilmiş eğitimin temel uygulama becerilerini geliştirmeye ve tanınırlığı artırmaya yardımcı olduğu ifade edilmektedir (Carter, Swanke, Stonich, Taylor, Witzke ve Binetsch, 2018). Simülasyon temelli öğrenme yöntemi kullanılarak geri bildirimin rolünü anlamak üzere yapılan bir başka araştırmada, bir öğrenme yöntemi olarak alan eğitimine olumlu katkısı olduğu belirtilmektedir (Kourgiantakis ve diğ., 2019). Yaşlılık döneminde depresyonu olan simüle müracaatçı ile yapılan çalışmada öğrencilerin simülatörü inandırıcı bulduğu, çevrenin gerçekçi olduğunu, eğitimden memnun oldukları ve bu yöntemin öğrencilerin klinik becerilerini geliştirmede katkı sağladığı ifade edilmektedir (Gellis ve Kim, 2017). Sosyal hizmet eğitiminde simüle müracaatç kullanımının öğretmedeki etkililiğini ve öğrencilerin yetkinliklerini değerlendirmek amaciyla 515 sosyal hizmet öğrencisini içeren 18 çalışmanın eleştirel değerlendirmesini yapan Logie ve diğerleri (2013) yöntemin öğrenciler tarafından iyi karşılandığını, bu değerlendirme yönteminin sosyal hizmet açısından kullanılabilmesi için geçerlilik çalışmalarının gerektiğini ifade etmektedirler. Objektif Yapılandırılmış Klinik Uygulamada on biri yeni mezun, yedisi yüksek lisans öğrencisi olan on sekiz öğrencinin lezbiyen olduğunu ifade eden bir müracaatçı ile etkileşiminin ele alındığı nitel bir çalışmada, öğrencilerin kendilerini yeterli hissetmediklerini, farklılık meselesini uygulamada nasıl kullanacaklarını bilmediklerini gördükleri belirtilmektedir (Logie, Bogo ve Katz, 2015). Holland Boorview (Kanada'da bulunan bir çocuk rehabilitasyon hastanesi) Sosyal Hizmet Simülasyon Eğitimi düzenlemiş ve eğitime katılan öğrencilere, simüle müracaatçı ile çalışmanın gerçek müracaatçıya duygusal ya da psikososyal zarar vereceği korkusu olmadan klinik becerilerini uygulama firsatı sunduğunu ifade etmişlerdir (Sunarich ve Rowan, 2017). Sosyal hizmet öğrencilerine simüle müracaatçı kullanarak görüşme içerisinde aktif dinleme becerilerini nasıl kullanacaklarını öğretmeyi amaçlayan bir başka çalışmada simüle müracaatçı kullanımının, öğrencilerin görüşme becerilerini öğrenmelerinde ve beceri kullanma noktasındaki güçleri ve eksik yönlerini tanımaları 
açısından yardımcı olduğu ifade edilmektedir (Rogers ve Welch, 2009). Sosyal hizmet eğitiminde madde kullanımı üzerine simüle müracaatçının kullanıldığ 1 ve bu açıdan bir ilk olan çalışmada, öğrencilerin değerlendirme ve müdahale becerilerinde kendilerine güvenlerini arttırdı ̆̆ atçının davranışlarını değiştirme ve madde bağımlılı̆̆ını azaltma konusunda kendilerine yönelik yapabilirlik algısına katkıda bulunduğu belirtilmektedir (Osborne, Benner, Sprague ve Cleveland, 2016).

Tüm bunlardan hareketle simüle müracaatçı kullanılarak yapılan sosyal hizmet eğitimlerinin öğrenciler açısından yararlı olduğu görülmektedir. Simüle müracaatçı uygulamasında zamana ve maddi kaynağa ihtiyaç duyulması, yöntemin en büyük zorluğu olarak belirtilebilir.

\section{Türkiye' de Simüle Müracaatçı Kullanılarak Yapılan Sosyal Hizmet Eğitimi Mümkün Olabilir mi?}

Sosyal hizmet eğitiminin olmazsa olmaz bir parçası olan alan uygulaması, öğrencilerin aldıkları teorik eğitimi uygulamaya aktarmalarında mükemmel bir fırsattır. Bu nedenle farklı üniversitelerde öğrenim gören sosyal hizmet öğrencileri, farklı dönemlerde ya da sürelerde olsa da eğitimlerinin önemli bir bölümünü herhangi bir kuruluşta uygulama yaparak geçirmektedir. Öğrenciyi izlemesi ve mesleki gelişimine katkı sunması için kurum danışmanları belirlenmekte ve öğrenciler üniversitedeki eğitsel danışmanlarının süpervizyonu altında uygulama yapmaktadır. Öğrencinin gerek müdahale ve süreç raporları gerekse de kurum danışmanları ile olan mesleki etkileşimleri değerlendirilerek dönem sonu notu verilmektedir. Bu durumlar çoğunlukla bölümlerinin alan uygulama rehberlerinde yazılı olarak belirtilmektedir. Eğitsel danışmanların öğrencilerin uygulama yaptığı günler ve saatlerde kuruluşlarda olması, onlarla incelemeye çıkıp görüşmelerini izlemesi vb. olanakları çoğu zaman bulunmamaktadır. Öğrencilerin bu becerileri kurum danışmanlarınca gözlenmeye çalışılmaktadır. Ancak bazı kurumlarda sosyal hizmet uzmanlarının olmaması nedeniyle öğrenciler farklı meslek elemanları gözetiminde uygulama yapmak durumunda kalabilmektedir. Bu nedenle öğrenciler sosyal hizmet mesleğinin daha çok "nasıl olması gerektiği değil, nasıl olmaması gerektiğini" öğrenme durumunda kalabilmektedir. Bu nedenle teorik eğitimleri boyunca öğrencilerin Miller (1990)'in tipolojisinde performans olarak belirttiği "nasıl yapılacağını gösterme" sinin gerek sosyal hizmetlere 
ihtiyaç duyan müracaatçlar gerekse de sosyal hizmet mesleğinin kendisi için son derece önemli olduğu düşünülmektedir. Simüle müracaatçların bunun için önemli bir kaynak olarak ele alınabilir.

Türkiye'nin farklı üniversitelerinde sosyal hizmet bölümlerinin olması, üstelik pek çok bölümde sosyal hizmet eğitimi almayan öğretim elemanlarının varlı̆̆ı, var olan bölümlerin öğrenci sayılarının giderek artması ancak buna karşın öğretim elemanı sayısının aynı oranda artmaması, bölümlerin fiziki olanaklarının yetersizliği; simüle müracaatçılar için gerekli eğitimlerin verilmesi, ücret ödenmesi, zaman harcanması gerektiği vb. gibi durumlar göz önüne alındığında, simüle müracaatçıların sosyal hizmet eğitiminde kullanılamayacağına dair bir düşünce belirebilmektedir. Halihazırda Türkiye'de sosyal hizmet eğitiminde simüle müracaatçlar kullanılmamaktadır. Çalışmanın temel argümanı, sosyal hizmet bölümü öğrencilerinin bir vakada mesleki bilgi ve değerlerin nasıl kullanılacağını gösterememesi, bu konuda sorunlar yaşaması dolayısıyla öğrencilerin bunu başarabilmesi için farklı tekniklere ihtiyaç duyulduğu ve simüle müracaatçların bunu gerçekleştirmede bir yöntem olarak kullanılabileceğidir. Bunun için öncelikli olarak simüle müracaatçıların yetiştirilmesi gereklidir. Şekil 2' de belirtilen adımlar ile simüle müracaatçların yetiştirilebileceği düşünülmektedir.

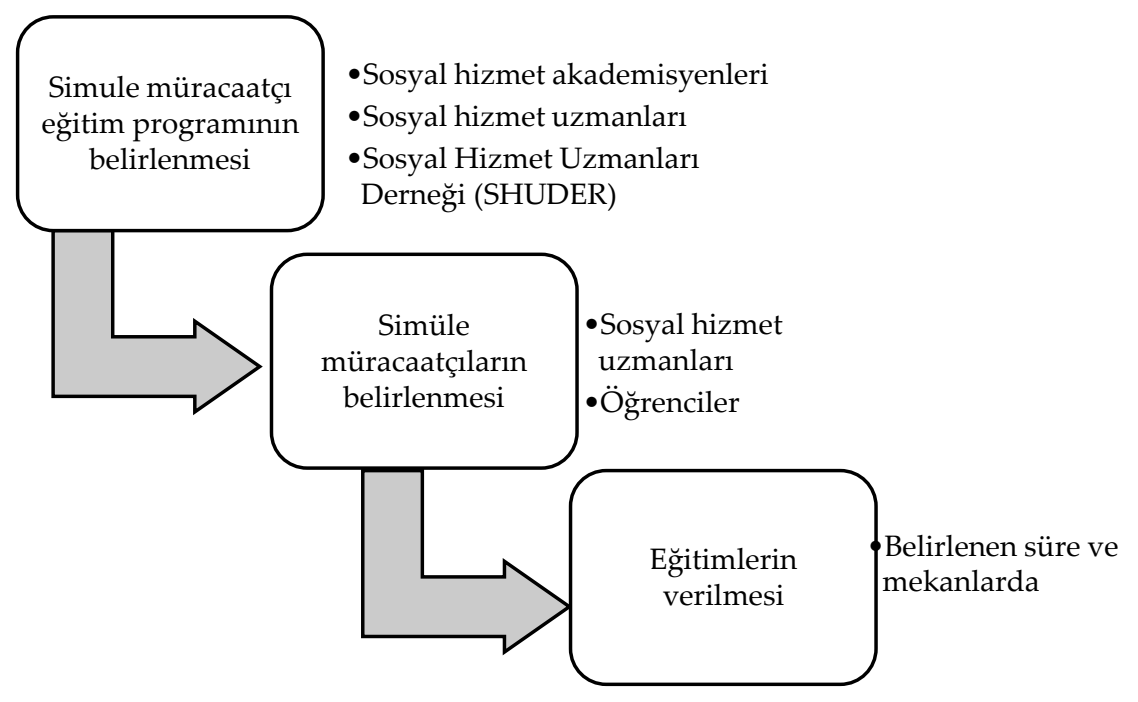

Şekil 2. Sosyal hizmet eğitiminde simüle müracaatçı yetiştirilmesi adımlan 
Şekle göre simüle müracaatçıların Türkiye'deki sosyal hizmet eğitiminde kullanılması için öncelikle müracaatçların yetiştirileceği eğitim programının belirlenmesi gerekmektedir. Örneğin, bir sosyal hizmet uzmanının karşılaşabileceği müracaatçı profillerine ilişkin çerçeve çıkarılıp senaryolar oluşturulmalıdır. Bu aşama, sosyal hizmet akademisyenleri öncülügünde sosyal hizmet uzmanları ve SHUDER aracılı̆̆ıla planlanabilir. Yine senaryo yazımına ilişkin ilgili disiplinlerden destek alınabilir. Sürecin ikinci adımı simüle müracaatçı olacak kişilerin belirlenmesidir. Bu müracaatçlar, sosyal hizmet uzmanları olabileceği gibi üniversitelerin oyunculuk bölümlerinde öğrenim gören ya da eğitimini tamamlamış, tiyatroya ilgi duyan ve yeteneği olan vb. kişiler arasından seçilebilir. Daha sonraki süreçte başlangiçta içeriği belirlenen eğitim, belirlenen sürede ve mekânlarda seçilen simüle müracaatçllara uygulanır. Bu eğitimin SHUDER aracılığıyla sertifikalandırılabilir. Son süreçte ise bu eğitimin sosyal hizmet bölümlerinde kullanılmasına ve yaygınlaştırılmasına ilişkin etkinlikler yürütülebilir. Böylece örneğin dersinde, şiddete maruz bırakılan kadınla feminist kuramla nasıl çalışacağını anlatan eğitimci, simüle müracaatçıyı dersine çağırarak öğrenciden aldığı bilgiyi uygulamaya aktarmasını isteyerek ve öğrenciye yaptığ rek öğrencinin bu konudaki beceri ve farkındalığını arttırmasına katkıda bulunacaktır. Bu sürecin etkililiğine ilişkin yapılacak araştırmalar yoluyla ilerleyen süreçlerde tıpkı sosyal hizmete uyarlanan OSCE sınavı gibi öğrencilerin değerlendirilebileceği özgün sınavlar yapılabilmesinin mümkün olacağını düşünülmektedir.

Simüle müracaatçılarla yapılan uygulamaların kaydedilmesi ve bunun üzerinden öğrencilere geribildirim verilmesi önem taşımaktadır. Bunun için de tıpkı Burdur Mehmet Akif Ersoy Üniversitesi'nde olduğu gibi uygulama sınıflarının oluşturulması önemlidir. Yurtdışında yapılan çalışmalardan hareketle, bu yöntemin uygulanmasının öğrencilerin mesleki becerilerini geliştirmede önemli bir fayda sağlayacağı, bu durumun da mesleğin bilimsel temellerinin ve toplumsal tanınırlığını doğrudan etkiyebileceği düşünülmektedir. 


\section{Sonuç}

Uygulamalı bir meslek ve akademik disiplin olarak sosyal hizmet eğitimde, öğrencilerin birey, grup ve toplumla çalışabilmeleri için gerekli bilgi, beceri ve değer temelini almaları beklenmektedir. Bu eğitimin veriliş biçimi, kullanılan yöntem ve teknikler sosyal hizmete dair bakış açısında son derece etkili olmaktadır. Öğrencilere aldıkları bilgileri uygulamaya nasıl aktarılacağının öğretilmesi etkili ve nitelikli uygulamaların yapılmasına, böylece mesleğin bilimsel temellerinin güçlendirilmesine ve toplumsal alanda kabul edilirliğine artmasına ve müracaatçların da sunulan hizmetten en üst düzeyde fayda görmesine katkı sağlayacağı düşünülmektedir. Simüle müracaatçların kullanımı bu amacı yerine getirmede bir araçtır. Özellikle sağlık alanındaki disiplinlerde yaygın bir biçimde kullanılan ve etkililiğine ilişkin çalışmaların yapıldığı simülasyon uygulamaları, yurtdışında sosyal hizmet eğitiminde de sıklıkla kullanılmakta ve hatta öğrencilerin değerlendirilmesi bu uygulamalar ile yapılabilmektedir.

Simüle müracaatçlar, sosyal hizmet uzmanlarının alanda karşılaştıkları olaylar, durumlar, kişilik özellikleri, vb. durumları temel alarak yazılan senaryoya göre müracaatçıyı canlandıran kişilerdir. Öğrenciler ders kapsamında öğrendiği bilgiyi bu müracaatçı ile birebir çalışarak uygulamaya aktaracaktır. Ders sorumlusundan ve müracaatçıdan alacağı geribildirimler aracllığıyla da kendisine ve yapmış olduğu uygulamaya dair farkındalık kazanacak, güçlü ve gelişmeye açk yönlerini görme imkânı elde edecektir. Böylece gerçek müracaatçı ile karşılaşmadan kendisini değerlendirip geliştirecek ve müracaatçıya zarar verme olasılığı en aza inecek ya da ortadan kalkacaktır. Bu sürecin ses ve görüntü kaydının alındığı uygulama sınıflarında yapılması hem uygulamayı yapan öğrencinin hem de onu izleyen diğer öğrencilerin mesleki gelişimleri açısından oldukça önemlidir. Özellikle kalabalık sınıflarda görüşmeyi izleme imkânı daha da önem kazanmaktadır.

Türkiye'de sosyal hizmet eğitiminde çoğunlukla rol oynama simülasyonları sınırlı bir biçimde kullanılmaktadır. Öğrencinin karşısındaki kişinin arkadaşı olduğunu bilmesi sınıf ortamında yaptıkları uygulamayı bilinçli veya bilinçsiz olarak etkilemektedir. Öğrenciler alan uygulamasına başlayıp gerçek müracaatçları gördüklerinde ise zorlanabilmektedirler. Bu nedenle sosyal hizmet eğitimi içerisinde simüle müracaatçıların kullanılmasının yararlı ola- 
cağı düşünülmektedir. Bunun için ise önce simüle müracaatçların yetiştirilmesi gerekmektedir. SHUDER öncülüğünde gerekli disiplinlerden de destek alınarak simüle müracaatçıların yetiştirilebileceği, bu müracaatçıların Türkiye'nin farklı sosyal hizmet bölümlerinin farklı derslerinde öğrencilerin mesleki gelişimlerine katkı sağlayacağı düşünülmektedir. Eğitim alan kişilerin derslerde yaşlı, engelli, kadın, çocuk vb. olarak yoksulluk, dışlanma, madde bağımlılı̆̆ı, intihar gibi herhangi bir sorunu yaşayan müracaatçıyı canlandırması yoluyla "sosyal hizmet uygulamasının nasıl yapılacağının" gösterilmesi, teori ve pratiği bütünleştirmelerinde öğrencilere yardımcı olacaktır. Bu yolla öğrencilerin daha fazla düşünümsel uygulama yapabilecekleri, sosyal hizmet uzmanı olarak mezun olduklarında alanda daha başarılı sosyal hizmet uygulamalarına imza atacakları ve bunun da mesleğin bilimsel tanınırlığının ve kabulünün artmasına katkıda bulunacağı düşünülmektedir. Bu konuda lisansüstü çalışmaların yapılması, yöntemin etkilerinin ortaya çkarılması mesleki gelişim açısından da oldukça yararlı olacaktır. 


\title{
EXTENDED ABSTRACT
}

\section{Simulated Clients as a Method for Integrating Theory and Practice in Social Work Education}

\author{
Eda Beydili Gürbüz \\ Duzce University
}

Social work is a practice-based profession Therefore, field practice has an important place in education. Students who learn the methods and techniques of working with individuals, groups and society in their lessons are expected to transfer this theoretical knowledge transfer into practice. However, researches (Erbay ve Sevin, 2013; Erbay, Adıgüzel ve Akçay, 2013) show that social work students do not feel ready to do field practice and cannot establish the relationship between theory and practice. The inability of students to establish this relationship causes them to experience problems when they encounter the real client. Such a situation can cause the client to be harmed and experience the problem even more deeply. Therefore, there is a need for different methods and techniques that will enable students to establish this bond in their education. The use of simulated client is one of these techniques

Simulation is a method that enables learning using a real problem in a realistic environment. There are different types of simulations, which are widely used in fields such as medicine, nursing and psychiatry, in parallel with the developing technology. Miller (1990) states that there are four basic frameworks for clinical evaluation. This first step is "knows knowledge". This situation constitutes the student's/doctor's professional knowledge base. This step can be measured by exams. However, knowledge is not enough, it must also "knows how". This refers to its competence. While exams conducted to evaluate students can measure students' knowledge and competencies, they are insufficient to "show how". Because in order to do this, it is necessary to observe the interaction of the student with the patient. On the other hand, can a student show how he / she can do? This last step is very difficult to test. Based on all these, it is thought that students knowing and demonstrating what and how they will actually do as a profession can be achieved by the good fit of all the steps in the pyramid. 
From the perspective of social work profession, simulation is not a new technique. Role-play method is a simulation technique frequently used in social work education. In this technique, the students take on the role of social worker and client and bring the aims and objectives of that lesson into place. However, the fact that the students know each other and the practice is carried out in an informal environment consciously or unconsciously affects the practice. For this reason, it is thought that the use of simulated clients will be more functional.

Simulated clients are those who have been trained to demonstrate all the features of a predetermined client. Unlike the role-play technique, the lecturer presents a simulated client that students have never seen before. The simulated client receives the necessary information from the lecturer beforehand and appears before the student as a client. At the end of the practice, the student is made aware of himself and the practice by giving feedback through an improved form. This process is recorded. Such a method enables the "show how" step that Miller calls performance. Practices using a simulated client are measured by the The Objective Structured Clinical Examination (OSCE ), especially in fields such as medicine, psychiatry, and nursing.

OSCE is also adapted to social work education. In this exam, the scenario created by the lecturer by working with a social worker beforehand is animated by the simulated client. At the end of the practice, the student is given feedback. The student also conducts a reflective interview with the simulated client. In this interview, feedback is given by discussing the student's awareness of the interview, how she/he combines social work concepts and values. There are various studies about the usefulness of social work education using simulated client.

Simulated clients are not used in social work education in Turkey. The main argument of this study is that the use of simulated clients would be more beneficial, as the role playing method, which is frequently used in education, is not real enough. For this, these simulated clients must first be trained. In this context, it was emphasized that it is important to initiate a training program in cooperation with social work academics, social workers and Turkish Association of Social Workers (TASW) . For this, first of all, a framework should be drawn about client profiles that a social worker might encounter and scenarios should be created. This stage can be planned by so- 
cial workers and TASW under the leadership of social work academics. Support can also be get from related disciplines regarding scriptwriting. The second step of the process is to identify the people who will be simulated clients. These clients may be social workers, as well as those who have studied or completed their education in the acting departments of universities, are interested in theater and have talent, etc. In the following process, the training, whose content is determined at the beginning, is applied to the simulated clients selected in the specified time and places. This training can be certified through TASW. In the last period, activities regarding the use and dissemination of this training in social work departments can be carried out. In this way, students will have the opportunity to work with the client before proceeding with the field practice, so the risk of harming the client will be eliminated or minimized. It is thought that the students doing such works in the field practice will contribute to the recognition and scientific basis of the profession

\section{Kaynakça / References}

Aksan, A., Kabasakal Çetin, A. Ilgaz, F. ve Gökmen Özel, H. (2017). Beslenme ve diyetetik eğitiminde simülasyon uygulamaları. Türkiye Klinikleri J Med EducSpecial Topics, 2(2), 96-103.

Alinier, G. (2007). A typology of educationally focused medical simulation tools. Medical Teacher, 29(8), 243-250.

Asakura, K., Bogo, M., Good, B. Ve Power, R. (2018) Teaching note-socialworkserial: using video-recorded simulated client sessions to teach social work practice. Journal of Social Work Education, 54(2), 397-404.

Badger, W. L. ve Macneil, G. (1998). Rationale for utilizing standardized clients in the training and evaluation of social work students. Journal of Teaching in Social Work, 16 (1-2), 203-218.

Badger, W. Lee ve Macneil, G. (2002). Standardized clients in the classroom: A novel instructional technique for social work educators. Research on Social Work Practice, 12 (3), 364-374.

Barrows, H. S. (1993). An overview of the uses of standardized patients for teachingand evaluating clinical skills. Academic Medicine, 68, 443-451.

Bogo, M. ve Rawlings, M. (2016). Routledge International Handbook of Social Work Education. I. Taylor, M. Bogo, M. Lefevre ve B. Teater (Ed.), Using simulation in teaching and assesing social work competence içinde (s.265-274.). NewYork: Routledge. 
Bogo, M., Regehr, C., Katz, E., Logie, C. ve Mylopoulos, M. (2011). Developing a tool for assessing students' reflections on their practice. Social Work Education: The International Journal, 30(2), 186-194.

Bogo, M., Regehr, C., Katz, E., Logie, C., Tufford, L. ve Litvack, A. (2012). Evaluating an objective structured clinical examination (OSCE) adapted for social work. Research on Social Work Practice, 22(4), 428-436.

Bradley, P. (2006). The history of simulation in medical education and possible future directions. Medical Education, 40, 254-262 doi:10.1111/j.13652929.2006.02394.x.

Carter, K., Swanke,J., Stonich,J., Taylor, S., Witzke, M. ve Binetsch, M. (2018). Student assessment of self-efficacy and practice Readiness Following Simulated Instruction in an Undergraduate Social Work Program. Journal of Teaching in Social Work, 38(1), 28-42.

Council on Social Work Education (CSWE). (2015). Educational policy and accreditation standards. $\quad \underline{\text { https://www.cswe.org/Accreditation/Standards-and-Poli- }}$ cies/2015-EPAS. adresinden erişilmiştir.

Çınaroğlu, S. (2013). Sağlık sektöründe hekim performansının değerlendirilmesi. Verimlilik Dergisi, 2, 81-99.

Darendeliler, F., Gökçay, G., Somer, A., Karakaş, Z., Çoban, A. İnce, Z., Eker Ömeroğlu, R., Sarıbeyoğlu, E. ve Bulut, E. (2002). Yapılandırılmış yansız klinik sinavlar İstanbul Üniversitesi İstanbul Tıp Fakültesi Çocuk Sağlığı ve Hastalıkları Anabilim Dalı deneyimi. Tip Eğitimi Dünyası, 7, 32-37.

Dikici, M. F., ve Yarış, F. (2007). Ondokuz Mayıs Üniversitesi Tıp Fakültesi klinik beceri eğitiminde standardize ve simüle hasta program. Turkiye Klinikleri JMed Sci, 27, 738-743.

Durmaz Edeer, A. ve Sarıkaya, A. (2015). Hemşirelik eğitiminde simülasyon kullanımı ve simülasyon tipleri. Hemşirelikte Eğitim Ve Araştırma Dergisi, 12(2), 121125.

Duyan, V. (2010). Sosyal hizmet: temelleri, yaklaşımları, müdahale yöntemleri. Ankara: Sosyal Hizmet Uzmanları Derneği.

Erbay, E., Adıgüzel, İ. B., ve Akçay, S. (2013). Sosyal hizmet öğrencilerinin sosyal hizmet uygulaması dersleri kapsaminda uygulama yürütecekleri kurumları tercih etme süreçleri. Toplum ve Sosyal Hizmet, 24(2), 95-107.

Erbay, E. ve Sevin, Ç. (2013). Hacettepe üniversitesi sosyal hizmet 4. Sınff öğrencilerinin eğitim süreçlerine ve gelecekteki meslek yaşamlarına ilişkin görüşleri. Toplum ve Sosyal Hizmet, 24(1), 25-39. 
Gaba, D. M. (2004). The future vision of simulation in health care. Qual Saf Health Care, 13(Suppl), i2-i10.

Gellis, D. Z. ve Kim, E. G.(2017). Training social work students to recognize later-life depression: Is standardized patient simulation effective?. Gerontology $\mathcal{E}$ Geriatrics Education, DOI: 10.1080/02701960.2017.1311882.

Göriş, S., Bilgi N. ve Korkut Bayındır, S.(2014).Hemşirelik eğitiminde simülasyon kullanımı.Düzce Üniversitesi Sağlık Bilimleri Enstitüsü Dergisi, 4(2), 25-29.

Hargreaves, R. Ve Hadlow, J. (1997). Role-play in social work education: Process and framework for a constructive and focused approach. Social Work Education: The International Journal, 16(3), 61-73.

Joyner, B. ve L. Young. (2006). Teaching medical students using role play: Twelve tips for successful role plays. Medical Teacher, 28(3), 225-229.

Kınıklı, G. İ., Erden, A., Cavlak, U. ve Erden, Z. (2017). Fizyoterapi ve rehabilitasyon eğitiminde simülasyon uygulamaları. Türkiye Klinikleri J Med Educ-Special Topics, 2(2), 104-110.

Kourgiantakis, T., Bogo, M. ve Sewell, M. K. (2019). Practice fridays: Using simulation to develop holistic competence. Journal of Social Work Education, 55(3), 551564 .

Linsk, L. N. ve Tunney, K.(1997). Learning to care: use of practice simulation to train health social workers.Journal of Social Work Education, 33(3), 473-489.

Logie, C., Bogo, M., Regehr, C. ve Regehr, G. (2013). A critical appraisal of the use of standardized client simulations in social work education, Journal of Social Work Education, 49(1), 66-80.

Logie, H. C., Bogo, M. ve Katz, E. (2015). "I didn't feel equipped”: social work students' reflections on a simulated client "coming out". Journal of Social Work Education, 51, 315-328.

MacDonald, C. ve Biegel, A. (2012, Ekim). A using role-play to teach competencies for acquiring behaviors as a social worker. North American Association of Christians in Social Work-NACSW-Conventionda sunulan bildiri. https://www.nacsw.org/Publications/Proceedings2012/MacDonaldCUsingRoleFINAL.pdf adresinden erişilmiştir.

Mercan, N. Tangül Özcan, C. ve Aydın, M. S. (2018). Psikiyatride ve iletişim eğitiminde simüle hasta uygulamaları. Psikiyatride Güncel Yaklaşımlar, 10(3), 302311.

Mıdık, Ö. ve Kartal, M. (2010). Simülasyona dayalı tıp eğitimi. Marmara Medical Journal, 23(3), 389-399. 
Miller, G. E. (1990). The assessment of clinical skills/ competence/ performance. Academic Medicine, 65 (9 Suppl), s63-s67.

Miller, M. (2002). Standardized clients: An innovative approach to practice learning, Social Work Education, 21(6), 663-670.

Mooradian, J. K. (2008). Using simulated sessions to enhance clinical social work education. Journal of Social Work Education. 44(3), 21-36.

Nimmagadda, J. ve Murphy, J. I. (2014). Using simulations to enhance interprofessional competencies for social work and nursing students. Social Work Education: The International Journal. 33(4), 539-548.

Osborne, A. V., Benner, K., Sprague, J.D ve Cleveland, N. I. (2016). Simulating real life: enhancing social work education on alcohol screening and brief intervention. Journal of Social Work Education, 52(3), 337-346.

Petracchi, H. E. ve Collins, K. S. (2006). Utilizing actors to simulate clients in social work student role plays. Journal of Teaching in Social Work, 26(1-2), 223-233.

Roberson, C. J. (2019). Simulation in social work education: A qualitative study of msw student development. Journal of Social Work Education, DOI:10.1080/10437797.2019.1671270

Rogers, A. ve Welch, B. (2009). Using standardized clients in the classroom: An evaluation of a training module to teach active listening skills to social work students. Journal of Teaching in Social Work, 29(2), 153-168.

Sunarich, N. ve Rowan, S. (2017). Social work simulation education in the field. Field Educator, 7(1), 1-9.

Sözen Şahne, B. Ulutaş D. ve Yeğenoğlu S. (2017). Eczacilık eğitiminde simülasyon uygulamaları. Turkiye Klinikleri J Med Educ-Special Topics, 2 (2), 81-85.

Şahin, G., Sağır Koptaş, O., ve Buzlu S.(2019). Standardize hasta kullanılarak yapılan bir ruh sağlığı ve psikiyatri hemşireliği klinik simülasyon deneyimi. Acıbadem Üniversitesi Sağlık Bilimleri Dergisi, 10(3), 486-492.

Sarmasoğlu, Ş. (2014). Hemşirelik eğitiminde standart hasta kullanımının öğrencilerin psikomotor beceri geliştirme süreçlerine etkisi. Doktora Tezi, Ankara: Hacettepe Üniversitesi.

Şendir, M. (2013). Kadın sağlığı hemşireliği eğitiminde simulasyon kullanımı. Florence Nightingale Hemşirelik Dergisi, 21(3), 205-2012.

Şenol, Y., Yardım, S. ve Başarıcı, İ. (2014). Öğrencilerin standart hasta uygulaması hakkındaki görüşleri: Birinci yıl sonuçları. Tıp Eğitimi Dünyası, 41, 19-26.

Taner, T., Yılmaz, Z. , Kütük, Z.B. ve Küçükkaya Eren, S. (2017). Diş hekimliği eğitiminde simülasyon uygulamaları. Türkiye Klinikleri J Med Educ Special Topics, 2(2), 86-95. 
Tuncay, T. (2016). Sosyal hizmet müdahalesini araştırmak: Uygulama kanitlarla güçlendirilebilir mi?. Toplum ve Sosyal Hizmet, 27(2), 115-129.

Turan, S., Üner, S. ve Elçin, M. (2011). Standart hasta geribildiriminin öğrencilerin güdülenme düzeyine etkisi. Balkan Medical Journal, 28, 43-48.

Tüzer, H. (2019). Simülasyona dayal eğitimde farkh çözümleme yöntemlerinin hemşirelik öğrencilerinin bilgi ve performansına etkisi. Yayınlanmamış yüksek lisans tezi, Ankara: Hacettepe Üniversitesi.

Uslu, Y. ve Yavuz van Giersbergen, M. (2019). Hemşirelik eğitiminde standardize hasta kullanımı. Kastamonu Eğitim Dergisi, 27(1), 271-280.

Whatling, T. ve Wodak, E.(1979). The simulated client in social work training. International Social Work, 22(2), 34-37.

\section{Kaynakça Bilgisi / Citation Information}

Beydili Gürbüz, E. (2020). Sosyal hizmet eğitiminde teori ve pratiği bütünleştirmede bir yöntem olarak simule müracaatçlar. OPUS-Uluslararası Toplum Araştırmaları Dergisi, 16(30), 2941-2965. DOI: 10.26466/opus.666764 